\title{
JÓZEF BUDNIAK
}

\section{Sekularyzacja w nauczaniu Jana Pawla II}

Od lat obserwujemy powolnie zachodzące zjawisko sekularyzacji spoleczeństwa przejawiające się emancypacją poszczególnych dziedzin życia spolecznego: polityki, życia gospodarczego, nauki, filozofii, kultury, oświaty, szkolnictwa i wychowania spod wplywu Kościolów i Wspólnot chrześcijańskich ${ }^{1}$. Problem ten dotyczy nie tylko Afryki i Azji, ale również Starego Kontynentu, a szczególnie zachodniej jego części. Umyka pamięci wielu ludzi, szczególnie Europejczyków fakt, że wielka cześć dorobku Europy w dziedzinie prawa, literatury, sztuki i filozofii nosi znamiona chrześcijaństwa i osiagnięć tych nie sposób w pelni zrozumieć i docenić, jeśli nie spojrzy się na nie z perspektywy chrześcijańskiej². Wskutek szerzenia się zobojętnienia, sekularyzacji ${ }^{3}$ i ateizmu, w sytuacji, w której

${ }^{1}$ Termin sekularyzacja w naukach spolecznych zdaniem J. Ma ri a ń sk i e g o występuje w rożnych znaczeniach: jako upadek bądź zanik religii, w następstwie którego następuje zanik dawnego wplywu religii, Kościola, dogmatów i symboli religijnych na życie spoleczeństwa; jako desakralizacja świata, czyli odejście od religijno-magicznego zrozumienia świata na rzecz logiczno-przyczynowego wyjaśniania związków między obiektywnymi zjawiskami; jako uwolnienie religii od spoleczeństwa i zepchnięcia jej do dziedziny wewnętrznego, osobistego, życia czlowieka; jako przenikanie treści religijnych do życia świeckiego w następstwie czego religijne wzory myślenia odgrywają się od swojego kontekstu i stają się częścią składową ogólnej kultury. Por. J. Mari ań ski: Religia i Kościól w spoleczeństwie pluralistycznym. Lublin 1993 s. 9. W leksykonach i słownikach socjologicznych termin sekularyzacja często traktowany jest równoznacznie z terminem sekularyzm. Por. Leksykon socjologii religii. Red. M. L i b is z ow sk a-Żó łtkow s k a, J. Mar i a n s k i. Warszawa 2004; Slownik spoleczny. Red. B. S z 1 a c h t a Kraków 2004. W wystapieniach Jan Paweł II przypisuje terminom sekularyzacja, sekularyzm równoznaczne znaczenie. Por. Adhortacje apostolskie Ojca Swiętego Jana Pawla II. Kraków 1996; Encykliki Ojca Świetego Jana Pawla II. Kraków 2005.

${ }^{2}$ Przemówienie J a n a Paw 1 a II do Uczestników III Międzynarodowego Forum Fundacji im Alcide De Gas peri e g o. Jan Pawel II o Europie.

www.opoka.org.p1/biblioteka/X/XU/naszaue/jp2-europa.html (z dnia: 1 X 2005).

3 Jan Paweł II w encyklikach, orędziach i wystapieniach terminowi sekularyzacja nadawał bardzo szerokie znaczenie definiujac sekularyzację jako stopniowe odchodzenie od religii, 
dobrobyt materialny $\mathrm{i}$ konsumpcjonizm przemieszany jest $\mathrm{z}$ zastraszającą nędzą $\mathrm{i}$ ubóstwem czlowiek wspólczesny zaczyna holdować zasadzie życia bez Boga. Moralnemu i duchowemu dziedzictwu grozi roztrwonienie pod wplywem wielorakich procesów, z których na plan pierwszy wysuwa się proces sekularyzacji, rozwój sekt i nowych ruchów religijnych ${ }^{4}$.

Sekularyzacja, jako zjawisko rozluźnienia więzi z religią oraz odchodzenie od zinstytucjonalizowanych form pobożności, towarzyszyla wszystkim religiom i wyznaniom od dawna, a jej rezultatem jest sekularyzm. Następstwa sekularyzacji, jak mówi Jan Pawel II, prowadzą do podcinania istniejacych w sercu czlowieka korzeni religijności ${ }^{5}$. Poszukiwanie nowych odmian religijności wiążących się bardziej z przyjemnościami niż obowiązkami, poszukiwanie religii innej niż daje ją świat i chrześcijaństwo powoduje, że co raz częściej swoje potrzeby duchowe czlowiek zaspakaja nie w Kościele, ale dokonuje poszukiwań wśród „religijnych jarmarków".

Proces sekularyzacji $\mathrm{w}$ spoleczeństwie dokonuje się $\mathrm{z}$ reguly stopniowo, spokojnie i samoczynnie, choć jego tempo uwarunkowane jest czasem, w jakim spoleczeństwo dokonuje reorganizacji swych struktur niezależnych od instytucji religijnych wyznaczając im wyspecjalizowane funkcje $\mathrm{e}^{6}$. Tak rozumiana sekularyzacja jest przeciwstawiana laicyzacji czyli świadomemu i celowemu dzialaniu prowadzacemu w rezultacie do zeświecczenia calości życia spolecznego na skutek wyrugowania religii z życia spolecznego i wyłączenia jej ze świadomości czlowieka.

Nagły wybuch wolności i wiążący się z nim posoborowy klimat w Kościele przyczynily się do zmiany obowiązujacego systemu wartości ${ }^{7}$ i poszukiwania między innymi nowych odmian religijności, niekiedy odleglych a nawet sprzecznych z nauką Kościola ${ }^{8}$. W prognozach fatalistycznych przewiduje się, że zmia-

jej wygasanie i związany z nim zanik potrzeb religijności, uwolnienie się społeczeństwa od religii i jej ograniczenie do wewnętrznego i osobistego życia człowieka. Wielowymiarowe definiowanie sekularyzmu powoduje, że jego przyczyny i przejawy mogą być wskazy wane i analizowane.

${ }^{4}$ J an Pawe 1 I I: Adhortacja apostolska Christifideles laici. W: Adhortacje apostolskie Ojca ..., 34

${ }^{5}$ Tamże, 4.

${ }^{6}$ F. A d a m s k i: Rodzina między sacrum a profanum. Poznań 1987 s. 81.

${ }^{7}$ Wywiad z kard. Josephem R a t z ing e re m z okazji 83. rocznicy urodzin J a n a P a w 1 a I I udzielony dla „Wiadomości” Katolickiej Agencji Informacyjnej i „Tygodnika Powszechnego". W:W co wierzy Kościót. "Tygodnik Powszechny”. R. 2003 nr 21 (2811), z dnia 25 maja 2003, s. 1 .

${ }^{8} \mathrm{~W}$ definicjach naukowych sekularyzacji spotykamy i taką, która definiuje sekularyzację jako wyrwanie treści religijnych $\mathrm{z}$ ich naukowego kontekstu i przeniesienie ich w obszar życia świeckiego. Por. P. M a z u r k i e w i c z: Sekularyzacja. W: Slownik spoleczmy ..., s. 1187. 
nie może ulegać też dotychczasowe miejsce religii: ze sfery publicznej trafi ona do sfery prywatnego życia.

Swoje stanowisko wobec sekularyzacja Jan Paweł II zawarl między innymi w Adhortacji apostolskiej Ecclessia in Europa twierdzac, że wielu wspólczesnych ochrzczonych Europejczyków, szczególnie tych którzy twierdza, że wiedzą co to jest chrześcijaństwo żyje tak, jakby Chrystus nie istnial [...] Miejsce pewności $i$ wielkich prawd wiary u wielu ludzi zajęto niejasne i malo zobowiqzujqce uczucie religijne, szerzq się równe formy agnostycyzmu i praktycznego ateizmu, które przyczyniaja się do pogłębienia rozdźwięku między wiara a ży$\mathrm{ciem}^{9}$.Papież Jan Pawel II w swoich wystapieniach odwoluje się do Pawla VI, który w Adhortacji apostolskiej Evangelii nunitandi z 1975 roku nazwal sekularyzm nieszczęsnq doktrynq, gdzie zwraca uwagę, w jaki to sposób przesiąknięta sekularyzacją wizja życia i przeznaczenia czlowieka wplywa na jego osobowość, twierdzac że czlowiek zajęty soba nie tylko stawia siebie w centrum wszelkiego zainteresowania, lecz śmie twierdzić, że jest zasadq i racja całej rzeczywistości ${ }^{\circ}$.

W wysoce rozwiniętym spoleczeństwie (sekularyzacja jest zjawiskiem cywilizacyjnym, które jest wkomponowane w źle pojęty nurt nowoczesności), coraz częściej mamy do czynienia z kompozytorami religijnymi tworzacymi swój światopogląd korzystając $z$ rozmaitych źródel $i$ wykorzystując $z$ wybranych przez siebie wspólnot religijnych wartości i przeslania takie, które akceptuja oni, a których realizacja nie powoduje wysiłku duchowego, wyrzeczeń, zamknięcia w ramy przyjętych form i nakazów. Indywidualizacja postaw może prowadzić do prywatyzacji wiary, wypaczając ją, zubożając, czyniąc z niej nową falę, na dzialanie której poddane są osoby o slabej wierze szukające nowego miejsca w nowej spoleczności. Taka postawa wobec religii może oslabiać wspólnotę kościelna, dlatego uznanie, że religia jest najbardziej osobistą sprawą każdego obywatela $i$ zepchnięcie jej do prywatnej sfery życia człowieka, ma swoje dalsze następstwa i wskazuje na zapotrzebowanie na nowe potrzeby religijne. Sekularyzacja prowadzi do zmiany postaw wobec wartości chrześcijańskich, powoduje, że nowoczesny czlowiek usiluje żyć bez religii i bez Boga. Sekularyzacyjna interpretacja wiary chrześcijańskiej prowadzi do jej erozji, z którq wiq̨że się głęboki kryzys sumienia i praktyki moralności chrześcijanskiej ${ }^{11}$.

Jan Pawel II, w latach swojego pontyfikatu, przemawial do każdego czlowieka, jak również do tych, którzy obawiają się dopuścić Jezusa do wlasnego

${ }^{9}$ Jan Paweł I I: Adhortacja apostolska Ecclessia in Europa. W: Adhortacje apostolskie Ojca ..., 47.

${ }^{10}$ J a n P a we 1 II: Adhortacja apostolska Pastores dabo vobis. W: Adhortacje apostolskie Ojca ..., 7 .

${ }^{11}$ Por. Drugie zgromadzenie Biskupów poświęcone Europie. W: Relatio ante disceptationem. OsRomPol z dn. 3 października 1999, s. 7. 
życia, aby nie utracić wolności wskazywal, że Chrystus jest zupelnie inna rzeczywistościa, nie ogranicza ludzkiej wolności, ale pomaga czlowiekowi. Papież już na początku swego pontyfikatu zwracając się do wiernych daje im nadzieję w slowach, Nie lękajcie się ${ }^{12}$.

W Adhortacji apostolskiej Pastores dabo vobis Jan Pawel II stwierdza, że na skutek subiektywizacji wiary wzrasta liczba chrześcıjan, którzy wykazuja mniejszq wrażliwość na obiektywnq $i$ integralnq naukę wiary, wybierajqc w sposób subiektywny to, co się podoba, co odpowiada osobistemu doświadczeniu i nie wymaga zmiany własnych przyzwyczajen $n^{13}$.

Zdaniem Jana Pawła II każda religia posiada wiele wartości duchowych będacych wyrazem duchowego wymiaru czlowieka. Niebezpieczeństwem dla nich jest materializm i sekularyzm.

Sekularyzacja ma różnorodne przyczyny i następstwa. Może również być wywolana uświadomieniem sobie przez wspólczesnego czlowieka wyzwolonego, majacego w nowoczesnych społeczeństwach dużo wolności, istniejacych ograniczeń i niejednokrotnie, jak mu się wydaje, niedojrzalego traktowania jego osoby w Kościele. Jednak proces sekularyzacji nie musi być negatywnie interpretowany. U osób, których wiara jest mocno ugruntowana i nie opiera się wylącznie na tradycji i konformizmie procesy sekularyzacji moga wplywać na poglębienie religijności ${ }^{14}$.

Obecnie, w następstwie rozwoju cywilizacji, sekularyzacja przyjmuje różne formy, a jej przejawy i siła oddzialywania moga być rożnie oceniane i interpretowane. Faktem jest, że sekularyzacja wytwarza duchowa próżnię, która wola o napelnienie - wszak świat dzisiaj bardziej slucha świadków niż nauczycieli, a tych drugich przyjmuje na tyle, na ile są oni świadkami ${ }^{15}$.

Zsekularyzowany świat nie jest $w$ stanie zaspokoić wszystkich potrzeb ani dać wyczerpującej odpowiedzi na pytania wspólczesności. Te odpowiedzi da

\footnotetext{
${ }^{12}$ Nie lękajcie się! Otwórzcie drzwi na oścież Chrystusowi! Otwórzcie dla Jego mocy zbawczej granice państw, systemów ekonomicznych, systemów politycznych, rozlegle dziedziny kultury, cywilizacji, postępu! Nie lękajcie się! Chrystus wie "co jest w czlowieku». On jeden! A dzisiaj czlowiek tak często nie wie, co $w$ nim jest, co jest w glębi jego umyshu i serca. Tak czesto jest niepewny sensu swojego życia na ziemi. Szarpie nim niepewność, która przeradza się w rozpacz. Pozwólcie zatem, proszę Was, blagam Was z pokora i ufnościa, pozwólcie Chrystusowi mówić do czlowieka. On jeden ma slowa zycia - tak, życia wiecznego. Por. G. W e i g e 1: Swiadek nadziei, Kraków 2000 s. 335.

${ }^{13} \mathrm{~J}$ an Paw eł I I: Adhortacja apostolska Pastorales dabo vobis. W: Adhortacje apostolskie Ojca ..., 7.

${ }^{14}$ F. A d a m s k i: Rodzina miedzy sacrum ..., s. 81

${ }^{15}$ Por. P a w e 1 V I: Adhortacja apostolska Evangelii nuntiandi, 41.
} 
chrześcijaństwo. Dlatego potrzeba budowania np. Unii Europejskiej na fundamencie wspólnych wartości, przy uwzględnieniu chrześcijańskich korzeni rożnych narodów, jest głęboko uzasadniona i podkreśla istotny wklad chrześcijaństwa i chrześcijańskiej koncepcji czlowieka w historię, kulturę różnych krajów ${ }^{16}$. Szczególnego znaczenia nabieraja slowa Jana Pawla II adresowane do calego Kościola w Europie zawarte w Adhortacji apostolskiej Ecclesia in Europa wskazujące droge życia społecznego i duchowego Niech caly Kościól w Europie przyjmie jako skierowane do niego nakaz i zachętę Chrystusa: opamiętaj się, nawróć się ,stań się czujny i umacniaj resztę, która miala umrzeć (Ap 3, 2) ${ }^{17}$.

Zdaniem Jana Pawla II sekularyzm jako zespól poglądów i zwyczajów broniących humanizmu calkowicie oderwanego od Boga wypaczonego przesytem konsumpcji nie może nie sprowadzić utraty poczucia grzechu oraz utraty wlasnej $d u s z y^{18}$. Papież zaznacza, że oslabienie znaczenia grzechu, a przede wszystkim utrata poczucia grzechu jest forma lub owocem negacji Boga: nie tylko w postaci ateizmu, lecz także sekularyzmu ${ }^{19}$. Sekularyzacja pozostaje wielkim znakiem obecnej sytuacji świata, który oczekuje na świadectwa wyznawców Chrystusa, uczniów Chrystusa. Przykladem na to stanowisko jest fakt, że we współczesnym świecie coraz częściej obserwuje się zjawisko stopniowego zaniechania praktyk religijnych, co przejawia się obniżaniem liczby wiernych uczestniczacych we Mszy św. niedzielnej, przystępujących do sakramentów czy nawet unikających praktyk postu, które byly kiedyś uregulowane przez przykazanie kościelne i przez liczne przepisy kościelne, a dziś, jak twierdzi Jan Paweł II epoka, w której żyjemy stwarza klimat bardzo niesprzyjajacy postowi, czyniąc dawne zakazy bardzo odlegle od wspólczesnej mentalności ${ }^{20}$.

Postępująca, choć powoli, sekularyzacja prowadzi do obojętności religijnej, w konsekwencji której następuje splycanie wiary, czego przejawem może być np. desakralizacji niedzieli.

Różne formy, szczególnie obecnie popularne, świętowania niedzieli powoduja, że następuje powolne odchodzenie od praktyk religijnych towarzyszących temu dniu. Niewatpliwie List Apostolski O Eucharystii Jana Pawla II mial zwró-

\footnotetext{
${ }^{16}$ Przemówienie J a n a P a w $\nmid$ a II do nowego Ambasadora Belgii w dniu 31 października 2002 r.. Por. http://www.kul.lublin.pl/dzwonkowski/przemówienia/2html (z dnia: 29 VIII 2005).

${ }^{17} \mathrm{~J}$ a n P aw e 1 I I: Adhortacja apostolska Ecclessia in Europa. W: Adhortacje apostolskie Ojca ..., 26

18 J an Pawe1 I I: Adhortacja apostolska Reconciliatio et Paenitentia. W: Adhortacje apostolskie Ojca ..., 18 .

19 Tamże, 18 .

${ }^{20} \mathrm{~J}$ an Pawe 1 II: Wezwanie do zachowania praktyk postu. Przemówienie wygloszone w dniu 17 lutego 1994 roku w czasie audiencji dla duchowienstwa diecezji rzymskiej. OsRomPol. R. 1994 nr 4 s. 23
} 
cić ponownie uwagę na odkrywanie pełni niedzieli jako Dnia Pańskiego podkreślając tym samym jej znaczenie dla wspólnoty parafialnej, do której jesteśmy włączeni przez chrzest, a tym samym stanowimy żywą spoleczność Kościoła. Dokumenty papieskie wskazuja na sens biblijny, teologiczny i duszpasterski niedzieli, będacej pierwszym dniem tygodnia, w który Jezus zesłal na apostolów Ducha Świętego. Niedziela, jako Dzień Pański nacechowany nadzieją, miłościa, radością winien być poświęcony shużbie Bogu, wspólnocie Kościoła, drugiemu czlowiekowi, rodzinie, gdy tymczasem jej prawdziwy charakter jest coraz częściej zatracany. Nierzadko jest traktowana jako „zakończenie tygodnia”, czas zwyklej rozrywki.

Odstępstwa od tradycji świętowania niedziel w ostatnim dziesięcioleciu, postępują powoli, ale niosą ze sobą znamiona sekularyzacji, co stanowi niebezpieczeństwo dla bogatego dziedzictwa religijnego i kulturowego wszak, jak wskazuja dokumenty Soboru Watykańskiego II, kultura pozostaje w ścistym zwiqzku z religia, zaś szacunek dla niej wiąże się $z$ szacunkiem dla jej religijnego komponentu ${ }^{21}$.

Jan Pawel II wielokrotnie podkreślał charakter niedzieli dnia poświęconego Bogu i wzywal wiernych, aby $z$ odnowionym zaangażowaniem przeciwstawiali się zeświecczeniu i aby cale ich życie bylo prawdziwym milym Bogu kultem duchowym $^{22}$. Niedziela jest symbolem tego, czym chrześctjaństwo było i jest dla Europy i dla swiata: nieustannego gloszenia Dobrej Nowiny zmartwychwstania Jezusa, świętowania Jego zwycięstwa nad grzechem i nad śmiercia, zaangażowania na rzecz pelnej radości człowieka ${ }^{23}$.

W polskich rodzinach coraz częściej widoczna jest obojętność religijna przejawiajaca się zastępowaniem, w najlepszym przypadku, Mszy Świętej transmisja radiową lub telewizyjną i kultycznq procesja do hipermarketu. Jest to niewatpliwie uleganie, jak w jednym ze swoich przemówień wskazal Jan Pawel II, $w$ pewnych środowiskach chronolatrii, naporowi ducha czasu i wtaczanie się do grupy lansujacej przekonanie, że we wspólczesnym świecie jesteśmy producentami i konsumentami, a nie dziećmi Bożymi. W takim przypadku musimy zadecydować, gdzie chcemy znaleźć swoja tożsamość: $w$ świecie producentów i konsumentów wybierajqc te wartości świata i jego filozofię prowadzqce do ciaglej pogoni za

${ }^{21}$ Deklaracja o stosunku Kościoła do religii niechrześcijańskich Nostra Aetate, 2. W: Sobór Watykański II. Konstytucje, Dekrety, Deklaracje. Poznań 1968.

${ }^{22}$ Wystapienie J a n a P awła I I przed modlitwa ,Anioł Pański” w Castel Gandolfo w dniu 3 sierpnia 2003 roku. W: http://www.kul.lublin.pl/dzwonkowski/przemówienia/2html (z dnia: 29 VIII 2005)

${ }^{23}$ Tamże. 
zdobywaniem rzeczy materialnych, czy jako dziecko kochajacego Ojca Niebiańskiego wszak jesteśmy dziećmi jednego Boga, a między sobą braćmi ${ }^{24}$.

Niedziela, kiedy nie zostaje przeznaczona na modlitwę, odpoczynek, komunię i radość traci swoje pierwotne znaczenie w następstwie czego „horyzont czlowieka staje się tak ciasny i nie pozwala mu dojrzeć nieba ${ }^{25}$, dlatego potrzebne są wyraźne, konkretne, inicjatywy duszpasterskie na plaszczyźnie wychowawczej, duchowej i spolecznej, pomagajqce przeżyć ja zgodnie z jej prawdziwym sensem $^{26}$.

Kościól w Polsce stracił wielu swoich wiernych na rzecz innego świata $i$ jego wartości, szczególnie ludzi mlodych. Świadomość obecności Boga i radość, jaką budzi wspólne przeżywanie wiary w rodzinie, wydaje się slabnąć, a przecież wiara jest darem Ducha Świętego, który czlowiek otrzymuje we wspólnocie ludu Bożego, otrzymuje także dla innych, aby się nim dzielit ${ }^{27}$.

Jan Pawel II inspirowal ludzi, przekonywal, aby nie poddawali się sekularyzacji wskazujac, że nawet masowe środki przekazu wspólczesnej epoki moga wzbogacać wartości intelektualne i duchowe każdego pokolenia. Ich rola oddzialywania wiąze się z faktem, że współczesna „nowa kultura” pozostaje pod ich wplywem.

Wzorem i przykładem wszelkiego przekazu jest słowo Boże ${ }^{28}$. Wielokrotnie i na rożne sposoby przemawial niegdyśs Bóg do ojców [naszych] przez proroków, a w tych ostatecznych dniach przemówil do nas przez Syna $(\mathrm{Hbr} 1,1)$.

Na progu trzeciego tysiąclecia ery chrześcijańskiej ludzkość jest na najlepszej drodze do stworzenia globalnej sieci blyskawicznej wymiany informacji, idei ocen we wszystkich dziedzinach życia, w tym również religii. Taką rolę pelnią media, a zwlaszcza Internet. Stają się one pierwszym areopagiem wspólczesnym, na którym nieustannie dokonuje się wymiana informacji, idei i wartości $^{29}$. Dzięki nowoczesnym technikom przekazu również sekularyzacja nie nabie-

\footnotetext{
${ }^{24}$ Przemówienie J a n a P a w ła I I do Polonii i Polaków za granicą. Austria, Wieden, Karlplatz 12 września 1983 r. Por. http://www.kul.lublin.pl/dzwonkowski/przemówienia/2html (z dnia: 29 VIII 2005).

${ }^{25} \mathrm{~J}$ an Pawe 1 I I: Adhortacja apostolska Ecclesia in Europa. W: Adhortacje apostolskie Ojca $\ldots, 82$.

${ }^{26}$ Tamże, 8

${ }^{27} \mathrm{~J}$ an P a we 1 I I: W imieniu Jezus petnia czlowieczeństwa. OsRomPol. R. $1991 \mathrm{nr} 2-3 \mathrm{~s}$. 34.

${ }^{28}$ Orędzie Ja na Paw la I I na Dzień Srodków Społecznego Przekazu W slużbie wzajemnego zrozumienia między narodami, OsRomPol. R.2005 nr 3 s. 9.

${ }^{29}$ Orędzie Ja n a P a w 1 a I I na Dzień Środków Spolecznego Przekazu Glosić Chrystusa na progu nowego tysiaclecia. OsRomPol. R. $2001 \mathrm{nr} 3$ s. 9.
} 
ra charakteru lokalnego, regionalnego, dotykającego wylącznie określoną spoleczność lecz staje się zjawiskiem ogólnoświatowym. Należy podkreślić, że stosunek Kościola do środków przekazu jest zasadniczo pozytywny i przychylny. Kościól popiera wolność slowa i prasy ${ }^{30}$ twierdząc, że możliwość przemawiania do tak szerokiego kręgu odbiorców, nie istniała nawet w najbardziej fantastycznych wyobrażeniach tych, którzy głosili Ewangelię przed nami ${ }^{31}$. Jan Pawel II wielokrotnie w swoich orędziach na Światowy Dzień Środków Spolecznego Przekazu podkreślal ich rolę i zdolność w wspomaganiu czlowieka w dażeniu do szczęścia i do realizacji samego siebie, twierdzac między innymi, że katolicy powinni odważnie otworzyć drzwi środków przekazu Chrystusowi, tak aby Jego Dobra Nowina byla głoszona $z$ dachów calego świata ${ }^{32}$ oraz wskazując, że sa one wspólczesną przestrzenią, w której ludzie dzielą się myślami i mogą wzrastać we wzajemnym zrozumieniu i solidarności ${ }^{33}$.

Środki społecznej komunikacji odgrywaja kluczową rolę w dzisiejszym świecie. Dysponuja tak wielka moca, że w ciagu zaledwie kilku dni potrafią wzbudzić pozytywną bądź negatywna reakcję ludności na wydarzenia, reakcje, odpowiadającą ich wlasnym celom ${ }^{34}$. Umożliwiają bardziej bezpośredni udział w wydarzeniach pobudzając jednocześnie do ofiarności względem tych, którzy doznaja cierpienia i borykają się z trudnościami ${ }^{35}$.

Nie można jednoznacznie wskazać z jaką moca środki masowego przekazu oddziaływaja na sekularyzację spoleczeństwa. $Z$ jednej strony dzięki mediom informującym coraz częściej o wydarzeniach, ideach, postaciach z życia religijnego, dokumentach kościelnych, inicjatywach kościelnych; głoszącym prawdziwie ludzkie wartości, stanowiącym niejednokrotnie swoiste uzupelnienie i pomoc w przygotowaniu się do spotkania się z Chrystusem we wspólnocie, jak i w podtrzymywaniu nowych wierzących na rozpoczętej już drodze wiary, uczestniczymy w rozprzestrzenianiu wartości chrześcijańskich i w budowaniu cywilizacji miłości. Środki społecznego przekazu niosą niejednokrotnie otuchę, stwarzaja sposobność do modlitwy ludziom zmuszonym do pozostania w domu lub w instytucjach publicznych, dają możliwość satelitarnego przekazu uroczystości reli-

${ }^{30}$ Orędzie J a n a Pa wła I I na Światowy Dzień Środków Społecznego Przekazu Telewizja w rodzinie kryteria wlaściwego wyboru programu. OsRomPol. R. $1994 \mathrm{nr} 4$ s. 8.

${ }^{31}$ Orędzie J a n a P a w la I I na Światowy Dzień Środków Spolecznego Przekazu Rozglaszajcie to na dachach. Ewangelia w epoce globalnej komunikacji. OsRomPol. R. $2001 \mathrm{nr} 4$ s. 4.

${ }^{32}$ Tamże, s. 5.

${ }^{33}$ Oręzie J a n a P a w 1 a I I na Światowy Dzień Środków Społecznego Środki masowego przekazu w sluzbbie prawdziwego pokoju w świetle encykliki „Pacem in terris”. OsRomPol. R. 2001 nr 3 s. 8.

${ }^{34}$ Tamże, s. 9.

${ }^{35}$ Orędzie Ojca Świętego na Wielki Post 2003: Więcej szczęścia jest w dawaniu anizeli w braniu. OsRomPol. R. 2003 nr 3 s. 7. 
gijnych, które docieraja do odbiorców na całej ziemi. Jan Paweł II podkreśla pozytywną rolę telewizji, która może pomnażać wiedzę ogólną i religijną rodziny, pozwalając uslyszeć slowo Boże, a tym samym umocnić religijną tożsamość rodziny i ksztaltować życie moralne i duchowe.

Z drugiej strony środki spolecznego przekazu posiadają wplyw negatywny na spoleczeństwo, a jak zaznaczył Jan Pawel II w orędziu na Światowy Dzień Środków Masowego Przekazu, posiadają one znamiona sekularyzacji, przejawiające się wpajaniem moralnego relatywizmu i religijnego sceptycyzmu, poprzez zachwalanie falszywych wizji życia, które przeciwstawiają się zasadzie wzajemnego szacunku oraz utrudniaja ustanowienie sprawiedliwości i pokoju ${ }^{36}$. Srodki przekazu, a przede wszystkim Internet, dostarczaja zdaniem Jana Pawła II mnóstwa pojęć, lecz nie uczą ich wartości, a kiedy te ostatnie zostają zaciemnione to czlowieczeństwo ulega pomniejszeniu i czlowiek latwo traci sprzed oczu swoja nadprzyrodzona godnośśc ${ }^{37}$.

Media, jak często podkreśla Papież, mogą być wykorzystane w sposób, który szkodzi integralnemu dobru ludzi, mogą wypaczać poglaady, wciagać w szkodliwe wspólnoty lansujące falszywe i destrukcyjne wartości zasłaniając moc i radość życia zgodnego z przykazaniami Bożymi i ewangelicznymi blogosławieństwami co powoduje, że wielu, zbyt wielu, ludzi myśli i żyje tak, jak gdyby Bóg nie istniat ${ }^{38}$.

Można niejednokrotnie w przekazach społecznych dopatrzyć się pomijania przesłania Ewangelii: spychania lub ignorowania doświadczeń religijnych. Świat mediów może jawić się niekiedy jako środowisko nieprzyjazne ewangelizacji jak pogański świat z czasów apostolskich.

Religia, szczególnie w czasach nacechowanych groźbą terroryzmu, zbyt często wykorzystywana byla jako narzędzie poglębiania istniejących już podziałów politycznych, gospodarczych i spolecznych, gdy tymczasem musimy ukazywać, że przekonania religijne sq inspiracjq dla pokoju, że zachęcaja do solidarności, sprzyjaja sprawiedliwości $i$ wspomagajq wolnośc $c^{39}$.Tylko kiedy postugujacy się środkami masowego przekazu znaja zasady porządku moralnego i wiernie je wcielają w życie przekazując prawdę o wartości i godności czlowieka, uczestni-

\footnotetext{
${ }^{36}$ Orędzie J a n a P aw 1 a I I na Światowy Dzień Środków Społecznego Przekazu Telewizja w rodzinie kryteria wlaściwego wyboru programu. OsRomPol. R. $1994 \mathrm{nr} 4 \mathrm{~s} .7$.

${ }^{37}$ Orędzie J a n a P a wl a II na Światowy Dzień Środków Przekazu Spolecznego wygloszone w dniu 24 stycznia 2002 r. „Wiadomości Katolickiej Agencji Informacyjnej”. R. $2002 \mathrm{nr} 5 \mathrm{~s}$. 33.

${ }^{38}$ J a n P a w e 1 I I: Encyklika Veritatis splendor. W: Adhortacje apostolskie Ojca ..., 88.

${ }^{39}$ Przemówienie J a n a P a w la II na formm Zgromadzenia Międzyreligijnego. OsRomPol. R. 2000 nr 1 s. 34
} 
czą w budowaniu dialogu i szerzeniu kultury życia. Aby świadczyć o Chrystusie czlowiek musi sam Go spotkać i rozwijać osobistą więź z Nim przez modlitwę, Eucharystię i sakrament pojednania, czytanie i rozważanie słowa Bożego, służbę innym. Wszak gloszenie Chrystusa jest nie tylko obowiązkiem, ale i przywilejem. Gloszenie Chrystusa w środkach przekazu (a z tym zjawiskiem spotykamy się w Polsce w ostatnich latach często: transmisje radiowe i telewizyjne Mszy św., z uroczystości kościelnych i państwach) to nie tylko nieodzowna część ewangelizacyjnej misji Kościola: to także wklad wzbogacający treści przekazywane przez media wnoszacy w nie życie, inspiracje i nadzieję ${ }^{40}$. Istnieje wedhug Jana Pawla II wielka potrzeba uświadomienia ludziom wielkiego wplywu mediów na ich życie co wymaga kontrolowania jakości przekazywanych treści i rozwijania konstruktywnego dialogu między producentami programów a ich konsumentami $^{41}$. Istnieje konieczność, jak podkreśla Jan Paweł II w Adhortacji apostolskiej Christifideles laici, aby na wszystkich drogach świata, a więc także na jego wielkich arteriach jakimi sq prasa, film, radio, telewizja i teatr, musi być gloszone zbawcze slowo Ewangelii ${ }^{42}$.

Zdaniem Jana Pawła II wspólczesne stanowisko wyznawców Chrystusa winno przeciwstawiać się sekularyzmowi glosząc prawdę o ludzkim życiu, objawiona w Wcielonym Slowie Biada mi, gdybym nie glosit Ewangelii $(1$ Kor 9,16). W wielu sytuacjach środki masowego przekazu, jak twierdzi Papież, powinny dokonać swoistego rachunku sumienia, aby uzyskać bardziej krytyczną świadomość wlasnych uprzedzeń lub braku szacunku dla przekonań religijnych i moralnych ludzi ${ }^{43}$.

Niejednokrotnie pojawiające się oznaki sekularyzacji w mediach są traktowane jako odpowiedź na nietolerancję i dyskryminację z tytulu religii i przekonań.

Polski przez dhugie lata nie będzie dotyczył w takim rozmiarze problem sekularyzacji, jaki obserwujemy w innych państwach europejskich, pomimo że nie brak tu cennych symboli chrześcijanskiej obecności, ale wraz z powolnym stopniowym wkraczajacym zeświecczeniem, powstaje niebezpieczeństwo, że stanq się

\footnotetext{
${ }^{40}$ Orędzie Jan a Paw 1 a I I na Światowy dzień Środków Spolecznego Przekazu, Glosić Chrystusa na progu nowego tysiqclecia. OsRomPol. R. $2000 \mathrm{nr} 3$ s. 9.

${ }^{41}$ Przemówienie J a n a P a w 1 a II do uczestników Międzynarodowej organizacji katolickiej ds. Środków Masowego przekazu Srodki masowego przekazu w slużbie Ewangelii. OsRomPol. R. $2002 \mathrm{nr} 4$ s. 26

${ }^{42}$ J an Pawel II: Adhortacja apostolska Christifideles laici. W: Adhortacje apostolskie Ojca $\ldots, 44$.

${ }^{43}$ Orędzie J a n a Paw $\nmid$ a I I na Światowy dzień Środków Społecznego Przekazu, Glosić Chrystusa na progu nowego tysiaclecia. OsRomPol. R. $2000 \mathrm{nr} 3$ s. 9.
} 
one jedynie pamiatkami przeszlości $i^{44}$. Nie ulega jednak watpliwości, że w złożonej historii Europy, chrześcijaństwo stanowi element kluczowy, gdyż wiara chrześcijańska uksztaltowala kulturę kontynentu wplatając się w jego dzieje.

Należy przypuszczać, że Polsce nie zagraża sekularyzacja globalna, zmieniająca świat w kierunku jego bezreligijności, której przejawem może być wyraźny spadek praktyk religijnych czy też pojawiające się trudności przeżywania osobistej wiary w kontekście spolecznych i kulturowym. Najbardziej widoczne symbole religijne codziennego dnia związane są z historią narodu, która jest silą napędowa historii, a sila napędowa kultury jest wiara religijna. $Z$ miejsc publicznych, z pewnością, nie znikną krzyże np. przy Pomniku Stoczniowców Gdańskich, krzyż przy Kopalni Wujek w Katowicach, gdyż stanowily i stanowią one część historii narodu. To fakt, że żyjemy i tworzymy spoleczeństwo coraz bardziej zlożone, pluralistyczne, w którym ścierajq się różne poglady, oceny i które oddala się od Kościola i Jego nauki ${ }^{45}$. Dlatego należy z uporem powracać do ,samego rdzenia" naszego chrześcijaństwa i naszego powolania, tak jak zakorzenione ono jest w Chrystusie.

Aby przeciwstawiać się sekularyzmowi musimy uczynić Kościól domem i szkolą miłości, to znaczy wspierać i uwypuklać duchowość wspólnoty, która jest warunkiem ewangelizacji Europy. Wspólnota zaś jest wypelnieniem tożsamości czlowieka, stworzonego na obraz Boży, to znaczy na obraz Trójcy - wspólnoty $(\mathrm{Rdz} 1,26)$.

Polsce zapewne nie grozi sekularyzacja, a raczej poszukiwanie w związku z transformacja polityczna, wprowadzaniem nowych mechanizmów rynkowych i gospodarczych nowego modelu religijności innego od dotychczasowych wzorów życia religijnego. W spoleczeństwie pluralistycznym, a tak możemy dziś określać spoleczeństwo polskie, majacym zwielokrotnione możliwości wyboru, charakteryzującym się różnorodnością idei światopoglądowych, poglądów politycznych oraz mającym szerokie możliwości samorealizacji mamy raczej do czynienia ze zmianami instytucjonalnej pozycji religii. W kraju, sądząc po symptomach, nie mamy do czynienia $\mathrm{z}$ zachodnioeuropejskim modelem sekularyzacji prowadzącym do zmierzchu religii. Wzrost modernizacji nie idzie tu w parze ze wzrostem sekularyzacji, a w tradycyjnie katolickim kraju, pomimo szybkiej modernizacji po roku 1989 utrzymuje się wysoki poziom deklaracji wiary i stosowania praktyk religijnych. Zadaniem niewątpliwie wymagającym badań jest ustalenie wskaźnika deklaracji do rzeczywistego zaangażowania.

\footnotetext{
${ }^{44}$ J an Paweł II: Adhortacja apostolska Ecclesia in Europa. W: Adhortacje apostolskie Ojca $\ldots, 7$.

${ }^{45}$ Przemówienie Jana Paw la II do Polaków z krajów Beneluksu. Bruksela 19 maja
} 1985. Por. http://www.kul.lublin.pl/dzwonkowski/przemówienia/2html (z dnia: 29 VIII 2005). 
Wydaje się, że młodzi ludzie w dzisiejszym świecie narażeni sa w sposób szczególny na wplywy sekularyzacji co może być następstwem ich fascynacji społeczeństwem konsumpcyjnym, dla którego idealem życiowym staje się dobrobyt materialny, który osiagnać należy za wszelką cenę i bezwarunkowo. Dodatkowo u ludzi mlodych, bardziej niż u doroslych, występuje silna tendencja do subiektywizacji wiary chrześcijańskiej. Młodzież dzisiejsza przeżywa w swoich rodzinach mniej intensywnie życie religijne, co pozostanie nie bez wplywu na następne pokolenia. W spoleczeństwie miejskim, charakteryzującym się większym dążeniem ku sekularyzacji w następstwie wylaniania się nowych kręgów i struktur spolecznych nie przyczyniajacych się do religijnej socjalizacji lub uszczuplających wplyw instytucji kościelnych, zaznacza się heterogenizacja postaw wobec religii ${ }^{46}$. Wlaśnie w młodzieży Jan Pawel II widzi przyszłość Kościola apelując do niej, prosi ją, aby nie przestawali szukać Chrystusa: [...] odkrywajcie we wlasnych oczach to pociagajace odbicie dobroci i piękna, którymi On sam napetnit wasze serca, gdy dat wam swego Ducha, a najglębsza prawde o czlowieku o nas samych można odkryć jedynie dzięki petnemu milości spojrzeniu Chrystusa. On, Pan wychodzi nam na spotkanie w tajemnicy Eucharystii. Dlatego nigdy nie przestawajcie Go szukać ${ }^{47}$.

${ }^{46}$ J. Ma ri a ń sk i: Religia i Kościól w spoleczeństwie pluralistycznym. Lublin 1993 s. 99.

${ }^{47}$ Homilia J a n a P a w 1 a I I wygłoszona w czasie Mszy św. dla środowisk akademickich Rzymu w dniu 14 grudnia 2005 r. OsRomPol. R. 2005 nr 2 s. 14. 